\title{
BMJ Open A cross-sectional survey of physical strains among offshore wind farm workers in the German exclusive economic zone
}

Marcial Velasco Garrido, Janika Mette, Stefanie Mache, Volker Harth, Alexandra M Preisser

To cite: Velasco Garrido M, Mette J, Mache S, et al. A cross-sectional survey of physical strains among offshore wind farm workers in the German exclusive economic zone. BMJ Open 2018;8:e020157. doi:10.1136/ bmjopen-2017-020157

- Prepublication history and additional material for this paper are available online. To view these files, please visit the journal online (http://dx.doi. org/10.1136/bmjopen-2017020157).

Received 17 October 2017 Revised 2 February 2018 Accepted 23 February 2018

Check for updates

Occupational Medicine, Institute for Occupational and Maritime Medicine (ZfAM), University Medical Center HamburgEppendorf, Hamburg, Germany

Correspondence to Dr. med. Marcial Velasco

Garrido;

m.velasco-garrido@uke.de

\section{ABSTRACT}

Objectives To assess the physical strains of employees in the German offshore wind industry, according to job type and phase of the wind farm (under construction or operation).

Design Web-based cross-sectional survey.

Setting Offshore wind farm companies operating within the German exclusive economic zone.

Participants Male workers with regular offshore commitments and at least 28 days spent offshore in the past year $(n=268)$.

Outcome measures Physical strains (eg, climbing, noise, working overhead, with twisted upper body or in confined spaces, vibration, heavy lifting, humidity, odours).

Results The most frequently mentioned physical strain was 'climbing' with $63.8 \%$ of the respondents reporting to be always or frequently confronted with climbing and ascending stairs during offshore work. Work as a technician was associated with a greater exposition to noise, vibrations, humidity, cold, heat, chemical substances, lifting/carrying heavy loads, transport of equipment, working in non-ergonomic positions and in cramped spaces, as well as climbing. Indeed, statistical analyses showed that, after adjusting for phase of the wind farm, age, nationality, offshore experience, work schedule and type of shift, compared with non-technicians, working as a technician was associated with more frequently lifting/carrying of heavy loads (OR $2.58,95 \% \mathrm{Cl} 1.58$ to 4.23), transport of equipment (OR $2.0695 \% \mathrm{Cl} 1.27$ to 3.33), working with a twisted upper body (OR $2.8595 \% \mathrm{Cl}$ 1.74 to 4.69 ), working overhead (OR $2.7795 \% \mathrm{Cl} 1.67$ to 4.58) and climbing (OR $2.3095 \% \mathrm{Cl} 1.40$ to 3.77 ). Working in wind farms under construction was strongly associated with increased and decreased exposure to humidity (OR $2.3295 \% \mathrm{Cl} 1.38$ to 3.92 ) and poor air quality (OR 0.58 $95 \% \mathrm{Cl} 0.35$ to 0.95$)$, respectively.

Conclusions Workers on offshore wind farms constitute a heterogeneous group, including a wide variety of occupations. The degree of exposure to detrimental physical strains varies depending on the type of job. Technicians are more exposed to ergonomic challenges than other offshore workers.

\section{INTRODUCTION}

Since the construction of the first offshore wind farm in Vindeby, Denmark, in 1991,

\section{Strengths and limitations of this study}

- Our study is one of the first to quantitatively assess physical strains of workers in the offshore wind industry.

- The study uncovers opportunities for interventions that could improve the health of offshore wind industry workers.

- The study design is cross-sectional and lacks an external control group; our findings must therefore be interpreted with caution and do not fulfil all causality criteria (eg, lack temporality).

- We cannot exclude, that the generalisability of our results is limited since, due to the lack of data on the offshore wind farm workforce, we cannot address the representativity of our sample.

the total capacity of offshore wind power has been continuously increasing worldwide. Indeed, the global cumulative offshore power capacity has grown in the past 10 years from less than 1000 megawatts (MW) in 2007 to more than $14000 \mathrm{MW}$ in 2017. ${ }^{2}$ Accordingly, there has also been a continuous increase in the workforce involved in the construction and operation of such offshore wind installations. Although the majority of offshore wind farms are located in the waters off the coast of Europe, the industry is expanding rapidly to China, Vietnam, South Korea, Japan, India and the USA. ${ }^{3}$

The offshore wind workplace is predominantly characterised by its remoteness and hostile environment: the average distance of the European installations from their respective coasts is currently 23.5 nautical miles $(43.5 \mathrm{~km}) .^{3}$ Offshore wind farms in the German exclusive economic zone (EEZ) are located up to 62 nautical miles $(115 \mathrm{~km})$ from the coast (in average 34 nautical miles in the North Sea $)^{2}$ mandating overnight accommodation. Typically, offshore wind farms consist 
of wind energy turbines, electric power transformation substations, and collector and converter substations, all spread over a variable water area. In Germany, the area of the wind farms ranges from $1 \mathrm{~km}^{2}$ to more than $50 \mathrm{~km}^{2}$ (with an average of $30 \mathrm{~km}^{2}$ ). ${ }^{2}$ The German offshore wind industry is considered to be one of the most developed worldwide. $^{3}$

Several professions are involved in the construction and operation of an offshore wind farm. In addition to the technical staff (electricians, mechanics, construction workers), site managers, caterers and paramedics are also subjected to the unique offshore working and living conditions.

The dimensions and technical characteristics of the installations impose specific demands on the workforce. Currently, the turbines have an average height of $90 \mathrm{~m}$ and a rotor diameter of up to $150 \mathrm{~m} .{ }^{45}$ As a result, working at extreme heights and in confined spaces, climbing, and carrying heavy equipment are unavoidable physical demands that employees are regularly confronted with. ${ }^{6}$

The aim of our study was to assess the physical strains (eg, working in awkward body positions, noise, vibration, heavy lifting) of employees in the offshore wind industry and to explore whether these physical demands differ according to job type (technicians and other jobs) or the phase of the wind farm (under construction and operation).

\section{METHODS}

\section{Study design and population}

An online cross-sectional survey was carried out between September 2016 and January 2017 of persons working on offshore wind farms located in the German EEZ of the North and Baltic Seas. By December 2016, there were 22 wind farms either already in operation or under construction in this area. ${ }^{2}$ Although there are no exact data regarding the number of offshore workers involved in these installations, it has been estimated that up to 5000 employees are directly or indirectly working on offshore wind farms within the German EEZ. ${ }^{7}$ This represents our source population. In order to ensure that our sample had sufficient exposure to the offshore environment, we restricted the sample to workers with regular offshore deployments or with a total of at least 28 days offshore during the last year if working on an irregular schedule (28 days represent round $10 \%$ of working days on a regular year). Preliminary analyses showed that women $(n=28)$ differed statistically in many aspects when compared with men (data not shown). Female workers were thus excluded from further analyses.

\section{Recruitment}

Participation was anonymous and voluntary. Subjects were recruited by contacting offshore companies operating in the German EEZ via telephone and email. We provided study information leaflets in both German and English through the channels of mail, email and personal communication to occupational physicians, health and safety managers, and human resources departments for distribution among their employees (eg, via intranet, newsletters, emails and word-of-mouth promotion). In addition, we promoted the study on relevant online platforms and forums. We also presented our study at the 'Round-table Maritime Safety Partnership', a regular meeting of key stakeholders organised by the German Offshore Wind Energy Foundation. ${ }^{8}$

\section{Questionnaire}

The online questionnaire was designed with the SurveyMonkey platform. It was accessible by electronic devices through its URL or QR-code, both provided in all written information materials (leaflets, emails, postings, etc) used for recruitment. The questionnaire was available in German and English. The first page of the questionnaire provided information on the study aims and characteristics, as well as a required consent item to be filled out prior to data collection. Access to the questionnaire was only granted after ticking off the sentence 'I hereby confirm that I have read and understood the study information and data protection policy above. I agree to participate'. Termination of the survey was possible at any stage. The questionnaire was piloted and refined with the help of offshore wind workers. Completion of the questionnaire-including topics and instruments not discussed in this paper-required a median time of $24 \mathrm{~min}$.

\section{Sociodemographic variables}

We collected data on gender, age, marital status ('single' or 'living in a relationship'), children under 18 years living at home ('yes' or 'no') and nationality ('German' or 'other').

\section{Job characteristics}

We collected data on offshore experience ('less than 1 year', ' 1 to 3 years', 'more than 3 years'), occupation type ('technician', 'other' (including site manager, catering, room service, quality management, paramedics, etc)), offshore work schedule ('regular' (including $14 / 14$ day rhythms as well as other models), 'occasional commitments'), work shifts ('rotating shift', 'non-rotating shift'), project phase of the wind farm ('under construction', 'operation'), transportation arrangements from accommodation to workplace ('ship', 'helicopter', 'both', 'none, living and working on platform'), location of accommodation ('onshore', 'hotel ship', 'offshore platform', 'construction ship') and type of room ('single cabin', 'double cabin').

\section{Physical strains}

Participants were asked to self-assess their level of exposure to a list of 18 physical demands and stressors: 'noise', 'vibrations/oscillation', 'humidity/moisture', 'cold', 'heat', 'frequent changes between heat and cold', 'odours', 'contact with chemicals or hazardous substances', 'lifting/carrying heavy loads', 'transport of aids (eg, personal protection equipment, tools) over long 
distances', 'working with twisted upper body/forward flexion of the spine', 'working with unsupported raised arms (overhead work)', 'reduced visibility', 'closed/ cramped quarters', 'climbing', 'poor air quality/air conditioning', 'restricted movement', 'unpredictable waiting times (eg, during 'weather days')' (see online supplementary material) during offshore deployments (modified from Bjerkan ${ }^{9}$ ). We included questions formatted as, 'How often are you exposed to...(physical strain)?'. Answer possibilities were presented on a 5-point Likert Scale with the categories 'always', 'often', 'sometimes', 'rarely', 'never/hardly ever'.

\section{Statistics}

Items left unanswered were treated as missing values and excluded from analysis. No imputation was done for any variable. Descriptive statistics are presented as frequencies and percentages for categorical variables. Bivariate and multivariate ordinal logistic regression was performed to estimate ORs with 95\% CIs for each physical strain according to occupation and phase of the wind farm adjusting for age, nationality, offshore experience, work schedule and type of shift. We chose an ordinal logistic regression approach (in opposition to a dichotomous one) to exploit the ordered levels of the dependent variables (physical strains). ${ }^{10}$ The statistical significance level was set at $p<0.05$. Statistical analyses were carried out using IBM SPSS Statistics for Windows V.23.0 (IBM Corp; released 2015; Armonk, New York, USA).

\section{RESULTS}

In total, 384 persons responded to the questionnaire (figure 1), although not all completed the entire survey. After application of the exclusion criteria, the final sample

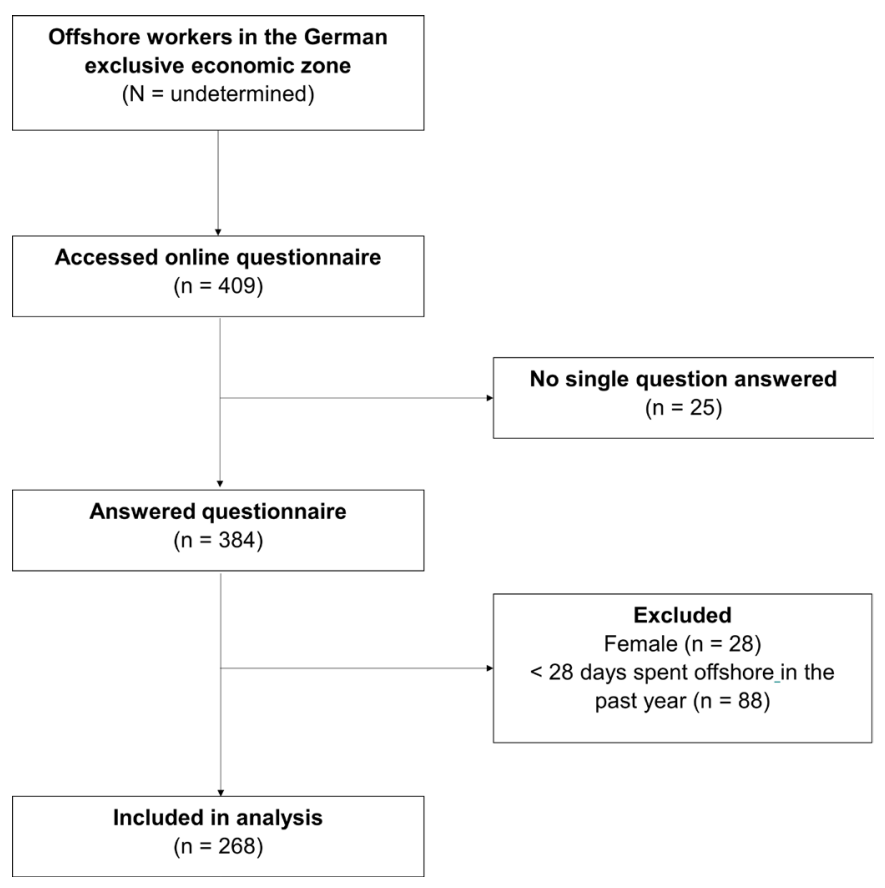

Figure 1 Study flow. consisted of 268 male offshore workers (figure 1). Participant characteristics are shown in table 1 . The majority of responders were German citizens $(89.3 \%)$. The sample consisted mainly of experienced offshore workers with only $5.2 \%$ reporting less than 1 year of work experience in this environment. Regarding specific occupations, technicians (operators, mechanics and installers) represented the largest group (48.9\%) followed by management staff $(36.6 \%)$. The sample also included health and safety managers, paramedics, and platform and ship crew. Approximately two-thirds of the responders were working on wind farms that were already operational $(64.8 \%)$, while $35.2 \%$ were working on installations in the construction phase.

As expected due to the exclusion criteria of this study, workers with a regular schedule of 14 days offshore work and 14 days onshore leave were over-represented (73.9\%). Half of these worked rotating shifts. Only $13.7 \%$ had onshore accommodations during their offshore deployments.

Table 2 shows the prevalence of physical strains among survey respondents. Overall, the most frequently mentioned physical strain was 'climbing' with $63.8 \%$ of the respondents reporting to be either always or often confronted with climbing and ascending stairs during their offshore rotations. Noise was reported to be always or often present by $55.6 \%$ of the participants, followed by vibrations with $52.2 \%$. Less frequent physical strains included working with reduced visibility, with $47.2 \%$ exposed either rarely or never, odours $(46.0 \%$ rarely or never exposed), working with chemicals $(41.3 \%$ rarely or never exposed), frequent changes between high and low temperatures (40.4\% rarely or never exposed), and working overhead (40.2\% rarely or never exposed). The distribution of the answers varied according to occupation with technicians reporting more frequent expositions to almost all strains (see online supplementary table A1). Distribution of answers also varied according to phase of the wind farm (see online supplementary table A2).

Bivariate analysis showed statistically significant differences according to the type of occupation for several physical strains (see table 3). Working as a technician was associated with increased exposure to noise, vibrations, high humidity, cold, heat, chemical substances, lifting/ carrying of heavy loads, transport of equipment, working in non-ergonomic positions and cramped spaces as well as climbing compared with other offshore workers.

Furthermore, working on installations under construction was associated with greater exposure to high humidity, cold, lifting/carrying of heavy loads, reduced visibility, working in cramped spaces, climbing and unpredictable waiting times compared with working on operational wind farms. Bivariate analysis also showed that working on a wind farm under construction was associated with decreased exposure to poor air quality.

Following adjustment for phase of the wind farm, age, nationality, offshore experience, work schedule and type of shift, technician work maintained a strong association 
Table 1 Demographic and occupational characteristics of participants included in the analysis

\begin{tabular}{lc}
\hline & $\begin{array}{l}\text { Study population } \\
(\mathbf{n = 2 6 8 )}\end{array}$ \\
\cline { 2 - 2 } Variable & $\mathbf{n}(\%)$ \\
\hline Age $(\mathbf{n = 2 6 8 )}$ & \\
20-34years & $116(43.4)$ \\
35-49years & $122(45.5)$ \\
250years & $30(11.2)$ \\
Nationality ( $\mathbf{n}=262)$ & \\
$\quad$ German & $234(89.3)$ \\
Other & $28(10.7)$ \\
\hline
\end{tabular}

Offshore experience

$(n=267)$

\begin{tabular}{|c|c|}
\hline$<1$ year & $14(5.2)$ \\
\hline 1-3years & $81(30.3)$ \\
\hline$>3$ years & $172(64.4)$ \\
\hline \multicolumn{2}{|l|}{ Occupation $(n=268)$} \\
\hline Management onshore (back office) & $15(5.6)$ \\
\hline Management offshore/supervisor & $83(31.0)$ \\
\hline Technician & $131(48.9)$ \\
\hline Other & $39(14.5)$ \\
\hline \multicolumn{2}{|l|}{ Work schedule $(n=268)$} \\
\hline Regular, 14/14 & 198 (73.9) \\
\hline Regular, other & $35(13.0)$ \\
\hline Occasional commitments & 35 (13.0) \\
\hline \multicolumn{2}{|l|}{ Work shifts $(n=263)$} \\
\hline Day shifts only & $130(49.4)$ \\
\hline Night shifts only & $1(0.4)$ \\
\hline Rotating shifts (day/nightshifts) & $132(50.2)$ \\
\hline \multicolumn{2}{|l|}{$\begin{array}{l}\text { Project phase of wind } \\
\text { farm }(n=268)\end{array}$} \\
\hline Under construction & $94(35.2)$ \\
\hline In operation & $173(64.8)$ \\
\hline \multicolumn{2}{|l|}{ Accommodation $(n=263)$} \\
\hline Offshore platform & $116(44.1)$ \\
\hline Offshore hotel ship & $67(25.5)$ \\
\hline Offshore construction ship & $44(16.7)$ \\
\hline Island/mainland hotel/flat & $36(13.7)$ \\
\hline \multicolumn{2}{|l|}{ Type of room $(n=262)$} \\
\hline Single cabin & $165(63.0)$ \\
\hline Double cabin & $97(37.0)$ \\
\hline \multicolumn{2}{|l|}{$\begin{array}{l}\text { Transfer from accommodation to } \\
\text { workplace }(n=241)\end{array}$} \\
\hline Ship & $76(28.9)$ \\
\hline Helicopter & $74(28.1)$ \\
\hline Both & $78(29.7)$ \\
\hline $\begin{array}{l}\text { None (eg, living and working on } \\
\text { platform) }\end{array}$ & $13(13.3)$ \\
\hline
\end{tabular}

with most of the abovementioned physical strains. In particular, strong associations $(\mathrm{OR}>2.0)$ were observed for lifting/carrying of heavy loads (OR 2.58, 95\% CI 1.58 to $4.23, \mathrm{p}<0.001$ ), transport of equipment (OR 2.06, $95 \%$ CI 1.27 to $3.33, p=0.003$ ), working with a twisted upper body (OR 2.85, 95\% CI 1.74 to $4.69, \mathrm{p}<0.001$ ), working overhead (OR 2.77, 95\% CI 1.67 to 4.58, $\mathrm{p}<0.001)$ and climbing (OR 2.30, 95\% CI 1.40 to 3.77, $\mathrm{p}=0.001$ ). In the adjusted model, phase of the wind farm also remained strongly associated with increased and decreased exposure to humidity (OR 2.32, $95 \%$ CI 1.38 to $3.92, \mathrm{p}=0.002)$ and poor air quality (OR $0.58,95 \% \mathrm{CI} 0.35$ to $0.95, \mathrm{p}=0.029$ ), respectively.

\section{DISCUSSION}

Despite the growing workforce involved in the construction and operation of offshore wind farms, little research has been done on this particular occupational group. Although considerable research exists on the working conditions, physical and psychological demands, and health issues of offshore workers from the offshore oil and gas industry, ${ }^{11}$ the physical strains experienced by employees in the offshore wind energy branch have thus far only been addressed in qualitative studies. ${ }^{12}$ The offshore wind and offshore oil and gas sectors share many similarities, but there remain important differences between the two industries, such as the type of installations and the extensive area of wind farms requiring frequent transport during offshore deployments. There are also similarities with the work in the onshore wind sector-that is, work in heights, climbing, type of installation-but comparability of both sectors is again limited due to the location of the installations, which demands, for example, the use of special safety and survival equipment during work. These differences justify a more in-depth investigation into this particular occupation and job environment.

Overall, we found high levels of exposure $(>50 \%$ of participants reporting being either always or often exposed) to climbing, noise and vibrations, and, although to a lesser extent, to handling heavy loads (42\%). Although our data are not fully comparable to those of the European Working Conditions Survey 2015, the levels of exposure to noise, vibration, cold, heat, chemicals and the handling of heavy loads appear to be higher than that of German high-skilled manual workers or within the construction and transportation sector. ${ }^{13}$ To our knowledge, no data regarding climbing are available from such a study format (survey). In our sample, climbing was the most frequently reported physical strain, with $21.3 \%$ and $42.5 \%$ of offshore workers reporting to either always or often being required to climb, respectively. Within the group of technicians, this was observed to be $27.2 \%$ and $48.8 \%$, respectively, a result that seems plausible in view of the dimensions of the installations (up to $115 \mathrm{~m}$ height ${ }^{4}$ ). Vertical climbing, as is typically required on wind energy installations-both onshore and offshore-is very physically demanding as additional muscular effort is required 


\begin{tabular}{|c|c|c|c|c|c|}
\hline & Always & Often & Sometimes & Rarely & $\begin{array}{l}\text { Never/hardly } \\
\text { ever }\end{array}$ \\
\hline & n (\%) & n (\%) & n (\%) & n (\%) & n (\%) \\
\hline Noise $(n=252)$ & 35 (13.9) & $105(41.7)$ & 87 (34.5) & $21(8.3)$ & $4(1.6)$ \\
\hline Vibrations/oscillation $(n=255)$ & 39 (15.3) & 94 (36.9) & $69(27.1)$ & $37(14.5)$ & $16(6.3)$ \\
\hline Humidity/moisture $(n=254)$ & $6(2.4)$ & $84(33.1)$ & 119 (46.9) & $36(14.2)$ & $9(3.5)$ \\
\hline Cold $(n=254)$ & $3(1.2)$ & $73(28.7)$ & $145(57.1)$ & $25(9.8)$ & $8(3.1)$ \\
\hline Heat $(n=254)$ & $3(1.2)$ & 55 (21.7) & $153(60.2)$ & 37 (14.6) & $6(2.4)$ \\
\hline $\begin{array}{l}\text { Frequent changes between heat and cold } \\
(\mathrm{n}=252)\end{array}$ & $8(3.2)$ & $48(19.0)$ & $94(37.3)$ & $81(32.1)$ & $21(8.3)$ \\
\hline Odours ( $n=252$ ) & $7(2.8)$ & 41 (16.3) & 88 (34.9) & $90(35.7)$ & $26(10.3)$ \\
\hline $\begin{array}{l}\text { Contact with chemicals or hazardous } \\
\text { substances }(n=252)\end{array}$ & $8(3.2)$ & $57(22.6)$ & $83(32.9)$ & $76(30.2)$ & $28(11.1)$ \\
\hline Lifting/carrying heavy loads ( $n=253$ ) & $16(6.3)$ & $90(35.6)$ & $86(34.0)$ & $51(20.2)$ & $17(6.7)$ \\
\hline $\begin{array}{l}\text { Transport of aids (eg, PPE, tools) over long } \\
\text { distances }(n=253)\end{array}$ & $44(17.4)$ & $76(30.0)$ & $73(28.9)$ & $43(17.0)$ & $17(6.7)$ \\
\hline $\begin{array}{l}\text { Working with twisted upper body/forward } \\
\text { flexion of the spine }(n=254)\end{array}$ & $9(3.4)$ & $82(32.3)$ & $89(35.0)$ & $51(20.1)$ & $23(9.1)$ \\
\hline $\begin{array}{l}\text { Working with unsupported raised arms } \\
\text { (overhead work) }(n=254)\end{array}$ & $1(0.4)$ & $44(17.3)$ & $107(42.1)$ & $70(27.6)$ & $32(12.6)$ \\
\hline Reduced visibility $(\mathrm{n}=252)$ & $0(0.0)$ & $38(15.1)$ & $95(37.7)$ & 83 (32.9) & $36(14.3)$ \\
\hline Closed/cramped quarters $(n=253)$ & $14(5.5)$ & $80(31.6)$ & 95 (37.5) & 47 (18.6) & $17(6.7)$ \\
\hline Climbing $(n=254)$ & $54(21.3)$ & $108(42.5)$ & $52(20.5)$ & $26(10.2)$ & $14(5.5)$ \\
\hline Poor air quality/air conditioning $(n=253)$ & $30(11.9)$ & $68(25.4)$ & $72(28.5)$ & $66(26.1)$ & $17(6.7)$ \\
\hline Restricted movement $(n=254)$ & $11(4.3)$ & $65(25.6)$ & $86(33.9)$ & $60(23.6)$ & $32(12.6)$ \\
\hline $\begin{array}{l}\text { Unpredictable waiting times (eg, during } \\
\text { 'weather days') }(n=254)\end{array}$ & $6(2.4)$ & $92(36.2)$ & $111(43.7)$ & $39(15.4)$ & $6(2.4)$ \\
\hline
\end{tabular}

in order to maintain balance. ${ }^{14}$ Although the use of fall-arrest systems obviously reduces the risk of major injury by preventing falls from great heights, slipping and being caught in the confined spaces of the interior of wind energy installations remain very real hazards associated with climbing. ${ }^{15}$ Offshore wind industry workers describe the climbing of ladders as being particularly challenging when combined with carrying heavy tools and wearing safety clothing (ie, survival suits), ${ }^{12}$ which is not required during work in onshore wind energy installations. The use of assist devices reduces climbing strain, ${ }^{16}$ while the presence of lifts obviously almost nullifies it. However, many older installations either do not have lifts or these are often inoperative, due to reparation or servicing.

We found patterns of physical and ergonomic strain for offshore wind workers to be associated with the type of job performed (technicians vs other occupations). Differences in work-related factors among specific job groups have been previously described for offshore workers in the oil and gas industry ${ }^{17}$ but, to our knowledge, not in the offshore wind industry. In particular, the technicians in our sample were subjected to higher degrees of working in non-ergonomic postures (overhead work, working with a twisted upper body or in forward flexion) during their assignments. They were also more frequently confronted with tasks involving heavy loads or bulky equipment, and were more often required to climb compared with offshore workers in other occupations. Although less frequently reported than the strain of climbing, overhead work and flexion, and rotation of the upper body represent relevant ergonomic strains. Performing tasks in such awkward positions, heavy lifting, as well as the generally strenuous and physically demanding nature of the offshore work, particularly among technicians, is often unavoidable. It is well known that these factors are occupational risk factors for the development of musculoskeletal disorders ${ }^{18}$ including workers in the offshore oil and gas industry. ${ }^{19}$ Overhead work causes muscle fatigue of the shoulder joint and reduced grip force in the hand. ${ }^{20}$ It has also been suggested to cause musculoskeletal pain in the neck and shoulder region, ${ }^{21}$ and is associated with arm and hand complaints. ${ }^{22}$ There is evidence that exposure to combinations of overhead work, heavy lifting and strenous work, as well as working in an awkward position (as observed for technicians in the offshore environment), all increase the risk of shoulder disorders. ${ }^{23}$ In addition, frequent work involving flexion or rotation of the upper body is a prognostic factor for recurrent 
Table 3 Association between occupation, phase of the wind farm, and physical strains

\begin{tabular}{|c|c|c|}
\hline Physical strain & Crude OR $(95 \% \mathrm{Cl})$ & Adjusted OR (95\% Cl)† \\
\hline \multicolumn{3}{|l|}{ Noise } \\
\hline Occupation (technician) $\ddagger$ & $1.88(1.19 \text { to } 2.99)^{\star \star}$ & $1.72(1.03 \text { to } 2.82)^{\star}$ \\
\hline Phase of wind farm (under construction)§ & $1.52(0.94$ to 2.45$)$ & $1.31(0,79$ to 2,18$)$ \\
\hline \multicolumn{3}{|l|}{ Vibrations/oscillation } \\
\hline Occupation (technician) $\ddagger$ & $1.75(1.12 \text { to } 2.73)^{\star}$ & $1.21(0.75$ to 1.96$)$ \\
\hline Phase of wind farm (under construction)§ & $1.48(0.93$ to 2.35$)$ & $1.25(0.76$ to 2.05$)$ \\
\hline \multicolumn{3}{|l|}{ Humidity/moisture } \\
\hline Occupation (technician) $\ddagger$ & $1.89(1.18 \text { to } 3.02)^{\star *}$ & $1.56(0.94$ to 2,57$)$ \\
\hline Phase of wind farm (under construction)§ & $2.63(1.60 \text { to } 4.33)^{\star \star \star}$ & $2.32(1.38 \text { to } 3.92)^{\star *}$ \\
\hline \multicolumn{3}{|l|}{ Cold } \\
\hline Occupation (technician) $\ddagger$ & $1.71(1.05 \text { to } 2.78)^{\star}$ & 1.68 (1.00 to 2.84$)$ \\
\hline Phase of wind farm (under construction)§ & $1.74(1.05 \text { to } 2.88)^{*}$ & $1.59(0,93$ to 2,72$)$ \\
\hline \multicolumn{3}{|l|}{ Heat } \\
\hline Occupation (technician) $\ddagger$ & $2.36(1.42 \text { to } 3.92)^{\star \star}$ & $1.83(1.08 \text { to } 3.13)^{\star}$ \\
\hline Phase of wind farm (under construction)§ & $1.34(0.81$ to 2.24$)$ & $1.02(0.59$ to 1.75$)$ \\
\hline \multicolumn{3}{|l|}{ Frequent changes between heat and cold } \\
\hline Occupation (technician) $\ddagger$ & $1.42(0.91$ to 2.23$)$ & $1.36(0.84$ to 2.21$)$ \\
\hline Phase of wind farm (under construction)§ & $1.16(0.72$ to 1.85$)$ & $1.09(0.66$ to 1.79$)$ \\
\hline \multicolumn{3}{|l|}{ Odours } \\
\hline Occupation (technician) $\ddagger$ & $1.28(0.82$ to 2.01$)$ & 1.18 (0.73 to 1.92$)$ \\
\hline Phase of wind farm (under construction)§ & 1.09 (0.68 to 1.76$)$ & $1.00(0.61$ to 1.65$)$ \\
\hline \multicolumn{3}{|c|}{ Contact with chemicals or hazardous substances } \\
\hline Occupation (technician) $\ddagger$ & $1.90(1.21 \text { to } 2.99)^{\star \star}$ & $1.76(1.09 \text { to } 2.84)^{*}$ \\
\hline Phase of wind farm (under construction)§ & $0.82(0.51$ to 1.30$)$ & $0.79(0.48$ to 1.29$)$ \\
\hline \multicolumn{3}{|l|}{ Lifting/carrying heavy loads } \\
\hline Occupation (technician)‡ & $2.99(1.53 \text { to } 3.78)^{\star \star \star}$ & $2.58(1.58 \text { to } 4,23)^{\star \star \star}$ \\
\hline Phase of wind farm (under construction)§ & $1.70(1.05 \text { to } 2.73)^{\star}$ & 1.47 (0.89 to 2.43$)$ \\
\hline
\end{tabular}

Transport of aids (eg, personal protection equipement, tools) over long distances
Occupation (technician) $\ddagger$
$2.40(1.53 \text { to } 3.78)^{\star \star \star}$
$2.06(1.27 \text { to } 3.33)^{\star *}$
Phase of wind farm (under construction)§
1.25 (0.78 to 1.98$)$
$0.99(0.61$ to 1.62$)$

\begin{tabular}{|c|c|c|}
\hline \multicolumn{3}{|c|}{$\begin{array}{l}\text { Working with twisted upper body/forward flexion of the } \\
\text { spine }\end{array}$} \\
\hline Occupation (technician) $\ddagger$ & $3.42(2.14 \text { to } 5.48)^{\star \star \star}$ & $2.85(1.74 \text { to } 4.69)^{\star \star *}$ \\
\hline \multicolumn{3}{|c|}{ Working with unsupported raised arms (overhead work) } \\
\hline Occupation (technician) $\ddagger$ & $3.37(2.10 \text { to } 5.43)^{\star \star \star}$ & $2.77(1.67 \text { to } 4.58)^{\star \star \star}$ \\
\hline \multicolumn{3}{|l|}{ Reduced visibility } \\
\hline Occupation (technician)‡ & $1.43(0.91$ to 2.25$)$ & $1.21(0.74$ to 1.96$)$ \\
\hline Phase of wind farm (under construction)§ & $2.18(1.34 \text { to } 3.53)^{\star \star}$ & $1.74(1.05 \text { to } 2.89)^{*}$ \\
\hline \multicolumn{3}{|l|}{ Closed/cramped quarters } \\
\hline Occupation (technician)‡ & $2.14(1.35 \text { to } 4.51)^{\star \star}$ & $1.79(1.10 \text { to } 2.93)^{\star}$ \\
\hline
\end{tabular}

Continued 
Table 3 Continued

\begin{tabular}{|c|c|c|}
\hline Physical strain & Crude OR $(95 \% \mathrm{Cl})$ & Adjusted OR $(95 \% \mathrm{Cl}) \dagger$ \\
\hline Occupation (technician) $\ddagger$ & $2.83(1.71 \text { to } 4.51)^{\star \star *}$ & $2.30(1.40 \text { to } 3.77)^{\star \star}$ \\
\hline Phase of wind farm (under construction)§ & $2.08(1.29 \text { to } 3.37)^{\star \star}$ & $1.74(1.05 \text { to } 2.89)^{\star}$ \\
\hline Occupation technician)‡ & $1.03(0.66$ to 1.61$)$ & $1.00(0.62$ to 1.60$)$ \\
\hline Phase of wind farm (under construction)§ & $0.61(0.38 \text { to } 0.98)^{*}$ & $0.58(0.35 \text { to } 0.95)^{\star}$ \\
\hline Occupation (technician) $\ddagger$ & $0.94(0.60$ to 1.46$)$ & $0.70(0.43$ to 1.13$)$ \\
\hline Phase of wind farm (under construction)§ & $1.18(0.74$ to 1.88$)$ & 0.99 (0.60 to 1.61$)$ \\
\hline \multicolumn{3}{|c|}{ Unpredictable waiting times (eg, during 'weather days') } \\
\hline Occupation (technician)‡ & $1.17(0.74$ to 1.85$)$ & 0.79 (0.48 to 1.31$)$ \\
\hline Phase of wind farm (under construction)§ & $2.08(1.27 \text { to } 3.39)^{\star *}$ & 1.64 (0.97 to 2.76$)$ \\
\hline
\end{tabular}

${ }^{*} \mathrm{p}<0.05 ;{ }^{* *} \mathrm{p}<0.01 ;{ }^{* * *} \mathrm{p}<0.001$.

†Adjusted for age, nationality, offshore experience, work schedule and type of shift.

‡Reference: any other occupation.

§Reference: wind farm in operation.

lower back pain. ${ }^{24}$ Lifting of heavy loads, particularly when associated with flexion and rotation of the trunk, is also associated with lower back pain. ${ }^{25}$ The relationship between lifting and moving heavy loads and lower back disorders has been well established for specific occupations, such as construction workers. ${ }^{2627}$ Since technicians are more exposed to such ergonomic constraints, they might be at higher risk for musculoskeletal disorders than other workers in the offshore wind energy industry.

In contrast to the type of job, the associations between phase of the wind farm and the physical strains were rather weak. After adjusting in the multivariate model to account for type of job-among other variables- the only factor which was strongly associated (OR >2.0) with the construction phase was exposure to humidity and moisture. This seems plausible, as construction work often takes place outdoors and in close proximity to water, whereas, during the operation phase, a large proportion of the work is performed inside the turbines. Interestingly, decreased exposure to poor air quality and/or air-conditioning was observed during the construction phase. Again, this could be a reflection of the increased time spent outdoors compared with the operation phase.

\section{Limitations}

The main limitation of our study is its cross-sectional design, which prohibits the establishment of sound causal links in the associations observed. In addition, our study lacks of an external control group from other occupational groups. Nevertheless, our internal comparison between technicians and non-technicians allows to identify different patterns of physical strains within offshore wind park workers.

Recall bias may have also been a problem concerning the frequency of exposition to physical strains, since some of the respondents filled out the survey while offshore (42.9\% of the respondents). Indeed, for those workers who were offshore at the time of the survey, we observed a tendency to report exposure to some of the strains (transport of aids, overhead work, reduced visibility, working in cramped spaces and climbing) less frequently (data not shown). This indicates that those answering while onshore may recall exposures to certain strains to be more frequent than they truly are. In other words, recall bias could have led to an over-reporting of the overall degree of exposure to some of the physical strains (eg, climbing or overhead work). Nevertheless, we do not expect recall bias to affect the observed differences in exposure between technicians and other jobs, since the proportion of workers responding to the questionnaire while offshore was similar among both groups $(42.7 \%$ among technicians, $43.1 \%$ among the other jobs).

In addition, we cannot assess whether the respondents to our survey are representative of the population of workers at offshore wind farms, thus we cannot exclude selection bias leading to limited generalisability. It has been estimated that approximately 5000 persons are regularly or sporadically working on such installations in the German EEZ. ${ }^{7}$ Based on this estimate, our study comprises roughly $5 \%$ of the total collective of offshore wind workers in this area. A true response rate cannot be calculated, since the web survey was also promoted via online platforms/ forums. Although there are no reliable data on the demographic characteristics of this group of German offshore wind industry workers, according to expert opinions (occupational physicians, health and safety managers), the gender distribution of the respondents to our survey does indeed correspond to the actual male-to-female ratio of the workforce in this sector. Since we excluded female workers in the detailed analyses of the health and working and living conditions of 
the study population, our results are only applicable to the male offshore wind farm workers.

Finally, the use of SurveyMonkey for conducting our survey implies data storage in the USA, which could raise concerns regarding violations of data protection legislation in the European Union. Although the collected data comprised personal information (eg, age, marital status, children, offshore experience, etc), particular individuals are not identifiable. First, age information was collected in categories (ie, birth dates were not recorded). Second, no information was collected on employers (ie, company) or on the name of the wind farm or location (ie, North Sea or Baltic Sea).

Furthermore, because the offshore wind energy industry is relatively young, there is a need for additional longitudinal research on the long-term effects of offshore work on the health and well-being of its employees.

\section{Implications for clinicians and policy makers}

Our findings have implications for occupational physicians and health safety managers taking care of offshore workers. Our results highlight the importance of possessing detailed knowledge of the specific job tasks and workplace conditions of employees when assessing fitness to work offshore and/or occupational risks. Indeed, jobs in the offshore wind industry differ substantially in terms of their physical demands, strains and associated health risks, and these differences must be considered in order to provide adequate and individually tailored occupational medical advice. Particular attention needs to be put on the ergonomic strains of technicians when providing such counsel and when planning preventive and health promotion activities on offshore installations.

\section{CONCLUSIONS}

Workers in the offshore wind industry comprise a heterogeneous group, which consists of a wide variety of occupations, including specific job tasks during the different phases of construction and operation, and work schedules, ranging from regular offshore commitments every 2 weeks with 12-hour shifts over 14 days, to sporadic deployments of only a few days. The degree of exposure to detrimental physical strains, therefore, also varies considerably depending on the type of job done offshore. Technicians in the offshore wind industry are more exposed to physical strains (eg, climbing, heavy load lifting or overhead work) particularly relevant for the development of musculoskeletal complaints than other offshore workers. This aspect should be taken into account when planning and providing interventions aiming to improve the working conditions of employees while offshore.

Acknowledgements The authors thank all offshore workers who responded to the survey. The authors also thank all company physicians, health and safety managers and all other staff who helped promote the survey. The authors also thank Rosalie McDonough for reviewing the paper and Robert Herold for statistical advice.

Contributors AMP and SM conceived the study and led the application for funding. MVG and JM designed the survey with inputs from SM and AMP. MVG ran the statistical analysis and wrote the first draft. All authors (MVG, JM, SM, VH, AMP) contributed to the interpretation of data, provided inputs on the first draft and revised the manuscript.

Funding German Federal Ministry of Education and Research (grant number: 01FA15029).

Competing interests None declared.

Patient consent Detail has been removed from these case descriptions to ensure anonymity. The editors and reviewers have seen the detailed information available and are satisfied that the information backs up the case the authors are making.

Ethics approval Ethics Review Committee of the Hamburg Medical Association.

Provenance and peer review Not commissioned; externally peer reviewed.

Data sharing statement № additional data are available.

Open Access This is an Open Access article distributed in accordance with the Creative Commons Attribution Non Commercial (CC BY-NC 4.0) license, which permits others to distribute, remix, adapt, build upon this work non-commercially, and license their derivative works on different terms, provided the original work is properly cited and the use is non-commercial. See: http://creativecommons.org/ licenses/by-nc/4.0/

(C) Article author(s) (or their employer(s) unless otherwise stated in the text of the article) 2018. All rights reserved. No commercial use is permitted unless otherwise expressly granted.

\section{REFERENCES}

1. Nixon N. Timeline: The history of wind power. The Guardian, October 17th 2008. https://www.theguardian.com/environment/2008/oct/17/ wind-power-renewable-energy (accessed 30 Sep 2017).

2. Fraunhofer Institute for Wind Energy and Energy System Technology (IWES). Wind Monitor - Development in Germany. Kassel: IWES, 2016. http://windmonitor.iwes.fraunhofer.de/windmonitor_en/ 4_Offshore/1_zubau/2_entwicklung_in_deutschland/index.html. (accessed 30 Sep 2017).

3. Global Wind Energy Council (GWEC). Global Wind Report 2016 Annual market update. Brussels: GWEC,, 2016. http://files.gwec.net/ register?file=/files/GWR2016.pdf. (accessed 30 Sep 2017).

4. Fraunhofer Institute for Wind Energy and Energy System Technology (IWES). Wind Monitor - Turbines Size. Kassel: IWES, 2016. http:// windmonitor.iwes.fraunhofer.de/windmonitor_en/4_Offshore/2 technik/3_Anlagengroesse/. (accessed 30 Sep 2017).

5. Stiftung Offshore Windenergie. Offshore Wind Energie - sauberer Strom aus dem Meer [Offshore wind energy - clean energy from the sea. Varel: Stiftung Offshore Windenergie, 2016. http://www. offshore-stiftung.de/offshore-windenergie. (accessed $30 \mathrm{Sep}$ 2017).

6. Velasco Garrido M, Mette J, Mache S, et al. Belastungen und Gefährdungen der Beschäftigten in der Offshore-Windindustrie [Demands and hazards of working in the offshore wind power industry]. Arbeitsmed Sozialmed Umweltmed 2017;52:134-7.

7. Federal Ministry for economic affairs and energy. Offshore wind energy - an overview of activities in Germany. Berlin: FMEAE, 2015. https://www.bmwi.de/Redaktion/EN/Publikationen/offshore-windenergy.pdf?_blob=publicationFile\&v=3. (accessed 30 Sep 2017).

8. Stiftung Offshore Windenergie. Vernetzung der maritimen Wirtschaft mit der Branche der Offshore-Windenergie 2 [Networking between maritime industry and offshore wind energy branch. Varel: Stiftung Offshore Windenergie,, 2017. https://www.offshore-stiftung.de/ Vernetzung. (accessed 30 Sep 2017).

9. Bjerkan AM. Work, health and safety culture/climate. A study of employees in the Norwegian oil and gas industry. Oslo: Centre for Technology, Innovation and Culture, University of Oslo, 2010.

10. Kleinbaum DG, Klein M. Logistic regression. A self-learning text. New York -Dordrecht-Heidelberg, 2010.

11. Gardner R. Overview and characteristics of some occupational exposures and health risks on offshore oil and gas installations. Ann Occup Hyg 2003;47:201-10.

12. Mette J, Velasco Garrido M, Harth V, Preisser AM, et al. "It's still a great adventure" - exploring offshore employees' working conditions in a qualitative study. J Occup Med Toxicol 2017;12:35.

13. European Foundation for the Improvement of Living and Working Conditions. European Working Conditions Survey 2015. Dublin: Eurofound, 2017. https://www.eurofound.europa.eu/data/europeanworking-conditions-survey. (accessed 15 Dec 2017). 
14. Barron PJ, Burgess K, Cooper K, et al. The effect of pitched and vertical ladder ergometer climbing on cardiorespiratory and psychophysical variables. Appl Ergon 2018;66:172-6.

15. Cooper K, Kirkpatrick P, Stewart A. Health effects associated with working in the wind power generation industry: a comprehensive systematic review. JBI Database System Rev Implement Rep 2014;12:327-73.

16. Barron PJ, Burgess K, Cooper K, et al. The physiological effect of a 'climb assist' device on vertical ladder climbing. Ergonomics 2017:60:1008-13.

17. Bjerkan AM. Work and health: a comparison between Norwegian onshore and offshore employees. Work 2011;40:125-42.

18. da Costa BR, Vieira ER. Risk factors for work-related musculoskeletal disorders: a systematic review of recent longitudina studies. Am J Ind Med 2010;53:285-323.

19. Chen WQ, Yu IT, Wong TW. Impact of occupational stress and other psychosocial factors on musculoskeletal pain among Chinese offshore oil installation workers. Occup Environ Med 2005;62:251-6.

20. Kinali G, Kara S, Yıldırım MS. Electromyographic analysis of an ergonomic risk factor: overhead work. J Phys Ther Sci 2016;28:1924-7.
21. Shin SJ, An DH, Oh JS, Dh A, Js O, et al. Changes in pressure pain in the upper trapezius muscle, cervical range of motion, and the cervical flexion-relaxation ratio after overhead work. Ind Health 2012:50:509-15.

22. Lowe BD, Shaw PB, Wilson SR, et al. Evaluation of a workplace exercise program for control of shoulder disorders in overhead assembly work. J Occup Environ Med 2017;59:563-70.

23. Linaker $\mathrm{CH}$, Walker-Bone K. Shoulder disorders and occupation. Best Pract Res Clin Rheumatol 2015;29:405-23.

24. van den Heuvel SG, Ariëns GA, Boshuizen HC, et al. Prognostic factors related to recurrent low-back pain and sickness absence. Scand J Work Environ Health 2004;30:459-67.

25. Hoogendoorn WE, van Poppel MN, Bongers PM, et al. Physical load during work and leisure time as risk factors for back pain. Scand $J$ Work Environ Health 1999;25:387-403.

26. Eva V, Lars A, Evy F, et al. Disability pensions due to musculoskeletal disorders among men in heavy occupations. A case-control study. Scand J Soc Med 1992;20:31-6.

27. Stürmer T, Luessenhoop S, Neth A, et al. Construction work and low back disorder. preliminary findings of the Hamburg construction worker study. Spine 1997;22:2558-63. 